\title{
CYTOMEGALOVIRUS: A TALE OF RESISTANCE
}

A desire to resist oppression is implanted in the nature of man.

Tacitus

\section{CITOMEGALOVIRUS: PRIČA O REZISTENCIJI}

Želja za otporom ugnjetavanju usađena je u ljudsku prirodu. Tacit

Marko Janković 1 , Tanja Jovanović ${ }^{1}$

${ }^{1}$ University of Belgrade, Faculty of Medicine, Institute of Microbiology and Immunology, Belgrade, Serbia

Correspondence: marko.jankovic@med.bg.ac.rs

\section{Abstract}

Cytomegalovirus (CMV) is a pathogen that affects the majority of the world's popula-

Keywords:

cytomegalovirus,

review,

antiviral resistance,

diagnostics,

drug resistance testing tion. It may exhibit a wide spectrum of clinical manifestations, ranging from asymptomatic infection in the healthy, congenital disease of the new-born to downright life-threatening illness in the immunocompromised. Initiating timely and adequate therapy can prove lifesaving. At times the virus develops resistance to specific drugs, an occurrence that can lead to the patient's demise. This mini-review explores the molecular aetiology and incidence of resistance, the antiviral arsenal that is at our disposal, as well as the diagnostic approaches to uncovering drug resistance.

\section{Sažetak}

Ključne reči:

citomegalovirus,

pregledni članak,

rezistencija na antivirusne

lekove,

dijagnostika,

testiranje rezistencije
Citomegalovirus (CMV) je patogen koji inficira većinu svetske populacije. Pokazuje širok spektar kliničkih manifestacija, počevši od asimptomatske infekcije u zdravih osoba, preko kongenitalne bolesti novorođenčeta, sve do po život opasnih oboljenja u populaciji imunokompromitovanih. Pravovremeno započinjanje optimalne terapije može biti spasonosno po bolesnika. Citomegalovirus razvija rezistenciju na specifične antivirusne lekove, što u pojedinim slučajevima ima za posledicu nepovoljan ishod. U ovom mini preglednom radu biće sagledani molekularna etiologija i incidencija rezistencije, spektar dostupnih antivirusnih lekova, kao i dijagnostičke metode za otkrivanje rezistencije na ove supstance.
Janković M. et al. MedPodml 2019, 70(4):21-26

(C)

The authors declare no conflicts of interest. doi:10.5937/mp70-23493

Editorial board: podmladak.med.bg@gmail.com e-ISSN: 2466-5525 
Cytomegalovirus is a ubiquitous pathogen affecting anywhere from 36 to $100 \%$ of the population $(1,2)$. It is more commonly encountered in developing countries (3). After primary exposure, the virus persists within its host for life, infecting such cells as lymphocytes, granulocytes, epithelial cells, fibroblasts etc. Only at times can it reactivate due to a number of stimuli, including immunosuppression and inflammation. In the immunocompetent person, the first contact with CMV most often results in asymptomatic infection and seldom requires treatment (4); it may also manifest as a mononucleosis-like syndrome, clinically much akin to its EBV infection counterpart. This clinical benevolence noted in the healthy can quickly go awry in those with enfeebled immune systems; CMV is an infamous bane of the immunocompromised, causing potentially life-threatening infections. It is a familiar viral opportunist in those with AIDS and patients with solid organ transplants (SOT) (5), as well as being on the forefront of hematopoietic stem cell transplant (HSCT) recipients' diseases. In SOT, HSCT and bone marrow transplant (BMT) recipients without antiviral therapy, CMV-associated disease is the main cause of morbidity and mortality (6-9). Likewise, it is the most common congenital viral infection in the world (10).

Nowadays, prompt administration of adequate antiviral therapy has reduced unwanted outcomes in many patients, and together with routine monitoring for timely virus detection can prove lifesaving. However, as with many other pathogens, resistance to therapy may loom large over the infected patient. Thankfully, a potent array of specific antivirals is at our disposal. Drugs standing at the vanguard of antiviral combat against CMV are ganciclovir (GCV), its prodrug valganciclovir (VAL), foscarnet (FOS), and cidofovir (CDV). All target the viral DNA polymerase. Reports of CMV isolates manifesting resistance to one or more of the approved drugs have so far been numerous, and this has enticed the need for antiviral resistance testing.

In this mini-review, we will uncover a significant portion of the aetiology behind the resistance to CMV antivirals. Herein, we discuss what is it that the term "resistance" truly implies; how much is it spread in those that are treated; what are the genetic and molecular foundations of this phenomenon; which drugs are used to combat CMV and how are we able to diagnose antiviral resistance itself.

What is resistance to antiviral drugs?

Resistance to an antiviral agent comes as a consequence of incomplete suppression of viral replication, i.e. the continuation of viral replication in the presence of the drug (11). Many factors influence the appearance of resistance, and are tied to the virus itself, the drug, as well as the patient. Protracted exposure to an antiviral along with viral replication due to immunosuppression are crucial elements in the development of drug resistance (5).
Resistance itself is an outcome of the evolution of single or multiple mutations that impart a range of resistance levels; as the mutations accumulate, the overall level will increase over time (12). Eventually, these changes may render the antiviral therapy unsuccessful in whole.

Upon suspicion of resistance, adequate laboratory testing should be initiated. Resistance may manifest as increasing viraemia, persisting viraemia or presence of disease in spite ongoing therapeutic efforts (5). In the setting of CMV infection, drug resistance may be rightfully assumed in the case of persisting or increasing plasma viral loads or CMV disease after several weeks of adequate therapy (1). This would, nonetheless, be a curious event during the first 6 weeks of therapy, although this was observed in immunodeficient pediatric populations $(13,14)$.

As resistance efficiently eliminates the usage of first-line antivirals, the employ of second-line drugs is necessary. This, however, may lead to toxicity inherent to these second-line agents, further endangering the patient. Finally, when alternative treatments are all spent, progressive viral infection may lead to the patient's demise.

\section{Incidence of CMV drug resistance}

The risk for the development of CMV drug resistance was highest in transplant recipients. However, incidence can vary to a great extent between subsets of transplant patients. Namely, CMV seronegative recipients of seropositive grafts of solid organ donors (D+/R- category) comprise the majority of cases (1). Within this group the incidence range is usually 5 to $10 \%$. Lung transplant patients are the most prevalent ones here. When GCV in solid organ transplant recipients is concerned, in general, resistance may go up to $13 \%$. Variation in incidences is influenced by the type of organ transplant, immunosuppressive therapy and antiviral prophylaxis, as well as exact resistance-determining criteria (15). Smaller incidences are reported in stem cell recipients - after roughly 3 months of prophylactic GCV or VAL therapy in clinical trials, resistance was detected in $0-4 \%$ of patients (16-18). In the setting of HSCT, ganciclovir resistance is indeed reported to be uncommon, except for a rapid emergence of resistance in children $(13,19,20)$. Resistance to FOS and CDV has also been observed in SOT and HSCT populations a number of investigations (5).

\section{Enter the genes: architects of resistance}

\section{UL97}

The product of the UL97 gene is a viral phosphotranspherase. The pUL97 includes conserved subdomains with precise functions, such as ATP binding, phosphate transfer and substrate binding. This enzyme is responsible for phosphorylating GCV (21). This phosphorylation is one of three such reactions crucial for the antiviral mechanism of the medication. When the viral DNA polymerase incorporates the phosphorylated GCV, its DNA conformation is altered, which ultimately results in termination 
of replication. The appearance of mutations in this gene might well be causative for resistance to GCV (21).

\section{UL54}

The copious coding faculties of the CMV harbor potential for a virus-specific DNA polymerase (Pol). This crucial enzyme, able to soundly reproduce viral DNA, is encoded for by the UL54 gene. Quintessential functions of Pol are 1) polymerization of nucleotides (in addition to release of pyrophosphate and binding of the incoming nucleotide triphosphate) and 2) proofreading, which is in essence 3'-5'-exonuclease activity. Resistance to antivirals may come as a consequence of such changes to the amino acid sequence that either 1) preclude the active drug-to-enzyme binding or 2) result in favoring of the removal of the incorporated drug (22-25). Should specific mutations in gene encoding for Pol arise, they might cause resistance to GCV, CDV and FOS; multidrug resistance phenotypes may consequentially appear as well (1).

\section{Enter the antivirals: the therapeutic panoply}

The advent of antiviral drugs has turned the tide in the struggle against viral infections. The first of these compounds saw the light of day in the mid XX century. It was not until 1960, however, that two of them, idoxuridine and methisazone, were enlisted for fighting viruses (26). Some of their worthy successors focused at CMV are ganciclovir, valganciclovir, cidofovir and foscarnet. All are aimed at the viral DNA polymerase (1).

It has been three decades to the year since intravenous GCV has been unsheathed in the fight against CMV. As administered, GCV is inactive; a prerequisite for giving a free rein to its antiviral activity is phosphorylation by the pUL97. The drug targets the Pol enzyme, eventually leading to replication stoppage. Namely, GCV induces decelerating and ensuing cessation of viral DNA chain elongation, but not outright obligate chain termination (27). The valyl ester prodrug of GCV is VAL and comes with a significantly better bioavailability and may be used instead of the intravenous GCV form in many clinical situations. It is unfortunate, then, that both of these pharmaceuticals often cause myelosuppression, particularly neutropenia $(28,29)$.

Unlike GCV and VAL, phosphonoformate sodium, the proverbial FOS, does not depend on prior phosphorylation by the pUL97. It instead blocks the release of pyrophosphate catalyzed by Pol, which has DNA chain termination as a result. The FOS is a pyrophosphate analog that is able to bind selectively to Pol at the pyrophosphate-binding site, thusly blocking cleavage of the pyrophosphate moiety from deoxynucleotide triphosphates. This in turn ceases DNA chain elongation (5). The disadvantages of FOS are the electrolyte abnormalities and notable nephrotoxicity which it may cause $(30,31)$.

Cidofovir (CDV) is also functional without the devices of a viral kinase, but is dependent on diphosphorylation by host cellular kinases in order to be activated (32). It is a nucleotide analog. The sole target of this antiviral molecule is Pol - once activated, it potently inhibits it. Regrettably, CDV has its drawbacks - an intravenously administered drug is linked to nephrotoxicity and neutropenia (33), while topical application is associated with application site irritation (34).

The resources poised against CMV disease has grown over time. Apart from the abovementioned pharmaceuticals, other medications are enlisted in combating CMV. Mentioned here will be leflunomide, maribavir, brincidofovir and letermovir. Among these, solely letermovir, a viral terminase complex inhibitor, has been recently approved by the FDA for virus prophylaxis in CMVseropositive adults that receive allogeneic HSCT. Up until 2017 maribavir and brincidofovir were still in the phase of clinical trials, but have been utilized for multidrug-resistant CMV infections on a compassionate basis. Maribavir prevents viral DNA synthesis and capsid nuclear egress. It directly inhibits the UL97 kinase. A valuable asset of this drug is that it is not attendant to nephrotoxicity or hematologic toxicity. Brincidofovir is an oral, bioavailable form of CDV. Finally, leflunomide is actually an antimetabolite employed in rheumatoid arthritis, but has been used off-label in CMV disease treatment as well as prophylaxis (35). These last four pharmaceuticals will not be further discussed here.

\section{Mechanisms of resistance}

The CMV drug resistance has been studied extensively. Preponderance for resistance mutations forming in the UL97 gene is noted, and is a consequence of GCV being the antiviral of choice for first-line therapy. The vast majority of isolates (over 90\%) which developed resistance after GCV therapy have at least one typical mutation in the UL97 gene (36). Mutations in this gene gather strongly at codons 460, 520 and 590/607. Some of the most regularly found mutations in ganciclovir-resistant isolates are M460V/I, H520Q, C592G, A594V, L595S, and C603W (36).

Mutations in the UL54 gene are infamous as they confer resistance to any or all of the so far mentioned drugs. Many mutations in the exonuclease domains allow for cross resistance between ganciclovir and cidofovir. Foscarnet resistance can be elicited by mutations at some non-conserved loci, as well as in and between catalytic regions II and VI; moreover, should they occur at region III, low-grade ganciclovir or cidofovir cross-resistance is possible $(27,37,38)$. A bona fide threefold, concurrent antiviral resistance encompassing GCV, cidofovir and foscarnet is rare; however, there are single UL54 mutations that may well lead to this scenario $(38,39,40)$.

Multiple mutations appearing sequentially in the setting of protracted CMV antiviral therapy are widely known $(41,12)$. Characteristically, the primary mutation confers resistance to ganciclovir; this is trailed by at least one UL54 Pol mutation subsequent to prolonged therapy.

Consequences of a drug-resistant CMV infection span the clinical spectrum anywhere from asymptomatic 
to severe. Initiating tests for determining the possible presence of a resistant virus should not be needlessly delayed. A schematized view of anabolism of GCV, CDV and FOS is represented on figure 1, while a graphic of UL54 and part of UL97 can be seen in figure 2 .

\section{"Resistance is futile": diagnosing resistance mutations}

Is there any merit to the well-known citation referenced in the subtitle of this paragraph? In the face of reliable diagnostic methods, is viral resistance truly a futile endeavor?
Phenotypic and/or genotypic assays are used in in vitro drug susceptibility testing for herpesviruses. Genotypic antiviral resistance testing is mainly based on detecting mutations in the pertinent viral UL97 kinase and UL54 DNA polymerase genes (1), with the diagnosis of CMV drug resistance habitually obtained via genotypic assays of the mentioned genes (21). It is worthwhile noting that interpretation of rarely reported mutations, as well as those that are unknown, presents as a problem.

The phenotypic assays are based on culturing calibrated viral inoculums in serial dilutions of an antiviral drug. If a classical plaque reduction assay (PRA) is utilized, the number of visible plaques formed on a

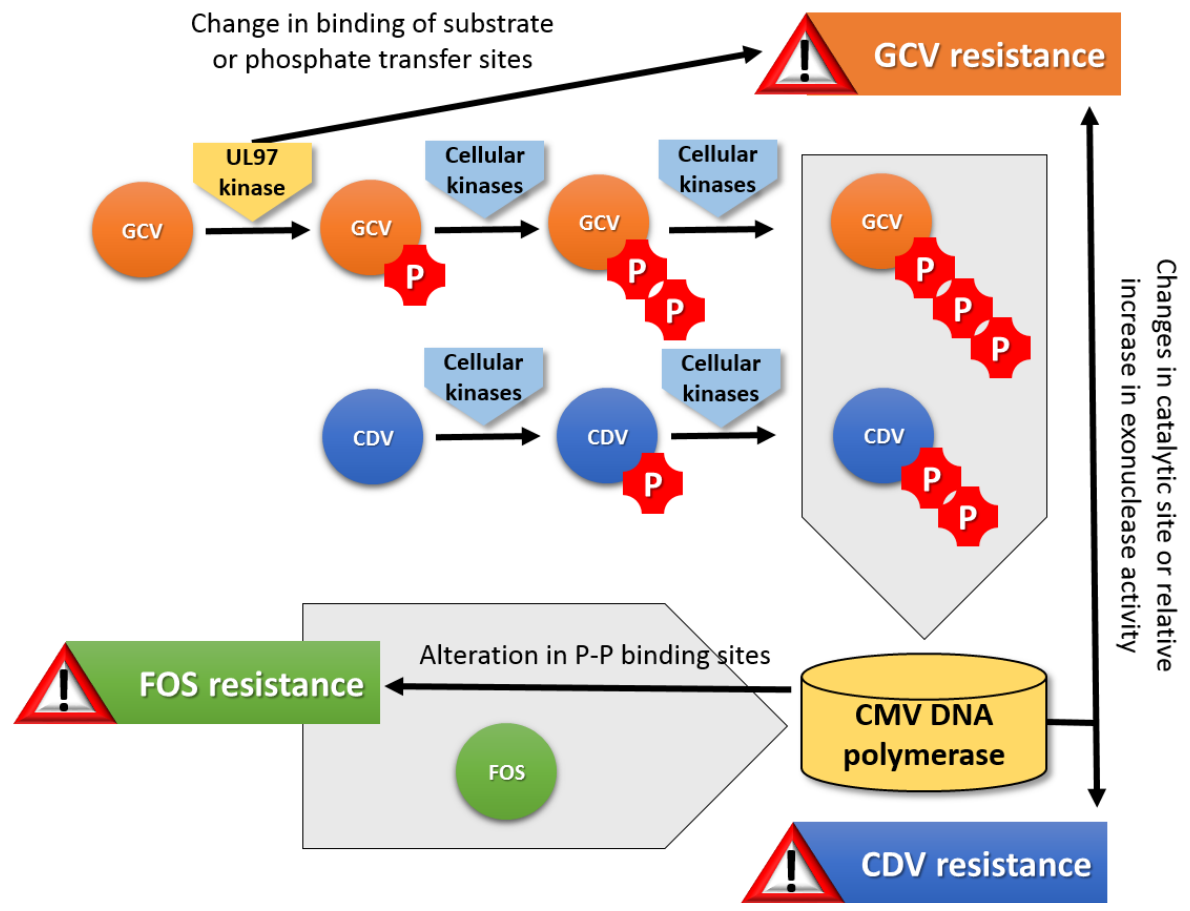

Figure 1. Target of ganciclovir (GCV), cidofovir (CDV) and foscarnet (FOS) - the CMV DNA polymerase. The UL97 kinase adds the initial phosphate to GCV, while the cellular kinases add two additional ones. Apart from the initial addition of the phosphate, same can be said for CDV. GCV triphosphate is the active form of the drug added to the viral DNA. Resistance results from mutations leading to changes in UL97 kinase or DNA polymerase. CDV diphosphate, the triphosphorylated active form of the drug. Resistance to CDV arises solely by DNA polymerase mutations. FOS is a pyrophosphate analog and does not necessitate activation. Resistance is conferred the same way as for CDV.

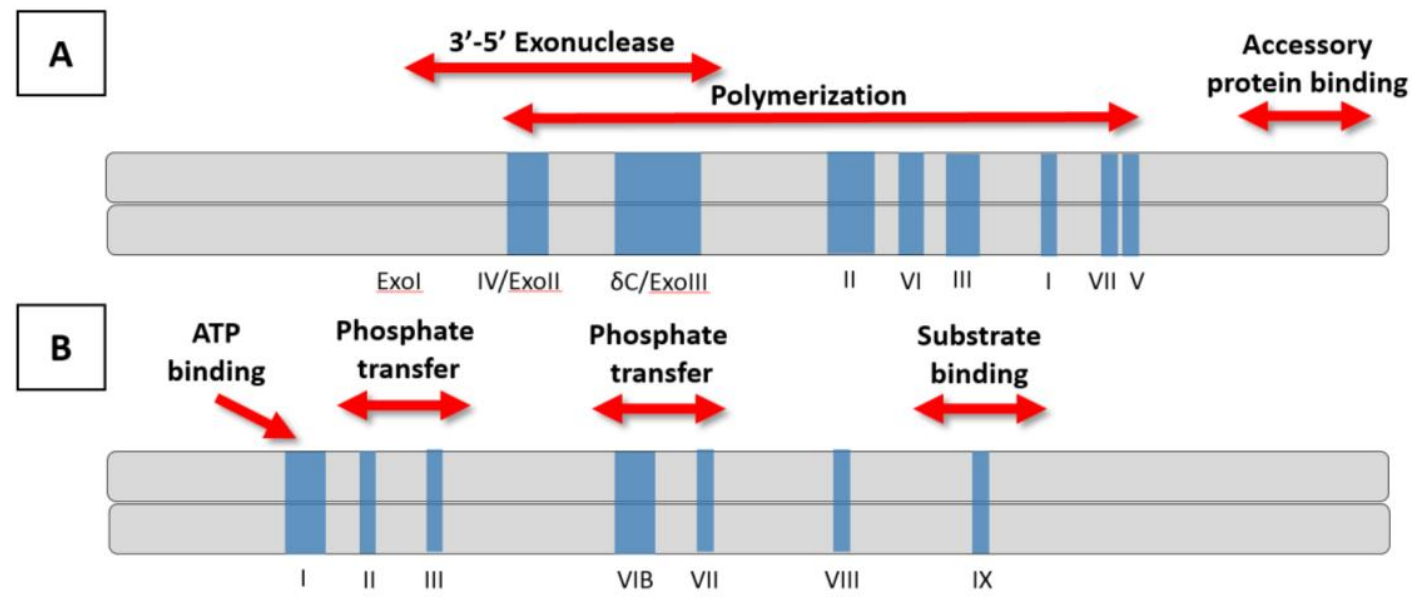

Figure 2. Schematics of the DNA polymerase UL54 gene and the UL97 gene kinase subdomain. Represented here are (A) the functional regions of the Pol enzyme, as well as (B) conserved functional regions of the pUL97. 
cellular monolayer during a determined incubation period represents the means of measuring viral growth. The PRA has its drawbacks, however, as it is labor-intensive, and influenced by numerous factors such as the viral inoculums, drug concentration range etc. Furthermore, CMV growth is slow, which protracts the time until a result is obtained. In summary, it is not a practical clinical tool, and molecular diagnostic tests are increasingly used.

Genotypic assays are in most cases a reliable way of diagnosing drug susceptibility in CMV. The accurate interpretation of these methods relies on the knowledge of the causative mutation (i.e. knowing that the specific mutation causes resistance to a certain drug), as well as the level or resistance and cross resistance that detected mutations confer. Genotypic tests are quicker to perform than phenotypic tests and do not have the need for a viral culture isolate the pathogen DNA can be amplified from patient samples directly. Although advanced, genotypic methods have limitations of their own. Namely, new changes to the viral DNA sequence that have not yet been identified may pose a diagnostic challenge. Moreover, difficulties with interpretation may arise when investigating effective levels of resistance that result from combinations of mutations. Finally, if viruses with an incriminating mutation represent only a fraction compared to the more abundant wild type virus, the sensitivity of detecting this specific subpopulation may be in question.

An important method worthy of mentioning is recombinant phenotyping, known as marker transfer. Briefly, mutations under suspicion of convening drug resistance are transferred to baseline viral strains, after which their influence on drug susceptibility can be determined by phenotypic assays (5).

So far, we have yet to fully outwit CMV and its stratagems in resisting our attempts to thwart infection. Infallible and all-encompassing methods are hitherto beyond our grasp.

\section{What does the future hold?}

Should we wish that the ongoing fight against drug resistant CMV goes in our favor, a more detailed insight into relevant viral, host and medication related characteristics is of great importance. So far, the genotypic techniques have enabled us to timely diagnose resistance in the vast majority of cases. Recombinant phenotyping further improves on the accuracy of this testing. Accessible and comprehensive databases of drug resistance mutations are an imperative for guiding therapeutic decisions. Broadening our knowledge on host and drug exposure factors that support the appearance of the resistant pathogen can be utilized in developing more advanced strategies for early detection and prevention. A search for more adequate antivirals - less toxic, more potent, that have minimal risk of cross-resistance - could hopefully yield good results.
References

1. Lurain NS, Chou S. Antiviral drug resistance of human cytomegalovirus. Clin Microbiol Rev. 2010 Oct; 23(4):689-712.

2. Knox GE. Cytomegalovirus: import of sexual transmission. Clin Obstet Gynecol. 1983 Mar; 26(1):173-177.

3. Chakravarty A, Kashyap B, Rathi K. The seroepidemiological study on cytomegalovirus in women of child bearing age with special reference to pregnancy and maternal-fetal transmission. Indian J Pathol Microbiol. 2005 Oct; 48(4):518-521.

4. Centres for Disease Control and Prevention. Cytomegalovirus (CMV) and Congenital CMV Infection. Available from: https:// www.cdc.gov/cmv/overview.html [Accessed 5th October 2019].

5. Strasfeld L, Chou S. Antiviral drug resistance: mechanisms and clinical implications. Infect Dis Clin North Am. 2010 Jun; 24(2):413-437.

6. Boeckh M, Fries B, Nichols WG. Recent advances in the pre vention of CMV infection and disease after hematopoietic stem cell transplantation. Pediatr Transplant. 2004 Jun;8 Suppl 5:19-27.

7. Boeckh M, Ljungman P, 2009. How we treat CMV in hematopoietic cell transplant recipients. Blood. 2009 Jun; 113(23):5711-5719.

8. Sia IG, Patel R. New strategies for prevention and therapy of cytomegalovirus infection and disease in solid-organ transplant recipients. Clin. Microbiol. 2000 Jan; 13(1):83-121.

9. Sun HY, Wagener MM, Singh N. Prevention of posttransplant cytomegalovirus disease and related outcomes with valgan ciclovir: a systematic review. Am J Transplant. 2008 Oct; 8(10):2111-2118.

10. Swanson EC, Schleiss MR. Congenital cytomegalovirus infection: new prospects for prevention and therapy. Pediatr Clin North Am. 2013 Apr; 60(2):335-349.

11. Stanojević M. Antivirusni lekovi. In: Savić B, Mitrović S, Jovanović T, editors. Medicinska mikrobiologija. Beograd, Srbija: Medicinski fakultet Univerziteta u Beogradu, CIBID; 2019. p.395.

12. Smith IL, Cherrington JM, Jiles RE, Fuller MD, Freeman WR, Spector SA. High-level resistance of cytomegalovirus to ganciclovir is associated with alterations in both the UL97 and DNA polymerase genes. J Infect Dis. 1997 Jul; 176(1):69-77.

13. Eckle T, Lang P, Prix L, Jahn G, Klingebiel T, Handgretinger R, et al. Rapid development of ganciclovir-resistant cytomegalovirus infection in children after allogeneic stem cell transplantation in the early phase of immune cell recovery. Bone Marrow Transplant. 2002 Oct; 30(7):433-439.

14. Wolf DG, Yaniv I, Honigman A, Kassis I, Schonfeld T, Ashkenazi S. Early emergence of ganciclovir-resistant human cytomegalovirus strains in children with primary combined immunodeficiency. J Infect Dis. 1998 Aug; 178(2):535-538.

15. Limaye AP. Ganciclovir-resistant cytomegalovirus in organ transplant recipients. Clin Infect Dis. 2002 Oct; 35(7):866-872.

16. Boivin G, Goyette N, Gilbert C, Covington E. Analysis of cytomegalovirus DNA polymerase (UL54) mutations in solid organ transplant patients receiving valganciclovir or ganciclovir prophylaxis. J Med Virol. 2005 Nov; 77(3):425-429.

17. Boivin G, Goyette N, Gilbert C, Roberts N, Macey K, Paya C et al. Absence of cytomegalovirus-resistance mutations after valganciclovir prophylaxis, in a prospective multicenter study of solid-organ transplant recipients. J Infect Dis. 2004 May; 189(9):1615-1618.

18. Boivin G, Goyette N, Rollag H, Jardine AG, Pescovitz MD, Asberg A et al. Cytomegalovirus resistance in solid organ tran splant recipients treated with intravenous ganciclovir or oral valganciclovir. Antivir Ther. 2009;14(5):697-704.

19. Prix L, Hamprecht K, Holzhüter B, Handgretinger R, Klingebiel T, Jahn G. Comprehensive restriction analysis of the UL97 
region allows early detection of ganciclovir-resistant human cytomegalovirus in an immunocompromised child. J Infect Dis. 1999 Aug; 180(2):491-495.

20. Springer KL, Chou S, Li S, Giller RH, Quinones R, Shira JE, et al. How evolution of mutations conferring drug resistance affects viral dynamics and clinical outcomes of cytomegalovirus-infected hematopoietic cell transplant recipients. J Clin Microbiol. 2005 Jan; 43(1):208-213.

21. Göhring K, Hamprecht K, Jahn G. Antiviral Drug- and Multidrug Resistance in Cytomegalovirus Infected SCT Patients. Comput Struct Biotechnol J. 2015 Feb; 13:153-9.

22. Blanco L, Bernad A, Blasco MA, Salas M. A general structure for DNA-dependent DNA polymerases. Gene. 1991 Apr; 100:27-38.

23. Cihlar T, Fuller MD, Mulato AS, Cherrington JM. A point mutation in the human cytomegalovirus DNA polymerase gene selected in vitro by cidofovir confers a slow replication phenotype in cell culture. Virology. 1998 Sep; 248(2):382-393.

24. Hall JD, Orth KL, Sander KL, Swihart BM, Senese RA. Mutations within conserved motifs in the 3'-5' exonuclease domain of herpes simplex virus DNA polymerase. J Gen Virol. 1995 Dec; 76(Pt 12):2999-3008.

25. Teo IA, Griffin BE, Jones MD. Characterization of the DNA polymerase gene of human herpesvirus 6. J Virol. 1991 Sep; 65(9):4670-4680.

26. Bauer DJ. A history of the discovery and clinical application of antiviral drugs. Br Med Bull. 1985 Oct; 41(4):309-14.

27. Gilbert C, Bestman-Smith J, Boivin G. Resistance of herpesviruses to antiviral drugs: clinical impacts and molecular mechanisms. Drug Resist Updat. 2002 Apr; 5(2):88-114.

28. Kalil AC, Freifeld AG, Lyden ER, Stoner JA. Valganciclovir for cytomegalovirus prevention in solid organ transplant patients: an evidence-based reassessment of safety and efficacy. PLoS One 2009; 4(5):e5512.

29. Crumpacker CS. Ganciclovir. N Engl J Med. 1996 Sep; 335(10):721-729.

30. Wagstaff AJ, Bryson HM. Foscarnet. A reappraisal of its antiviral activity, pharmacokinetic properties and therapeutic use in immunocompromised patients with viral infections. Drugs. 1994 Aug; 48(2):199-226.

31. Deray G, Martinez F, Katlama C, Levaltier B, Beaufils H, Danis M, et al. Foscarnet nephrotoxicity: mechanism, incidence and prevention. Am J Nephrol. 1989;9(4):316-321.
32. De Clercq E. Clinical potential of the acyclic nucleoside phosphonates cidofovir, adefovir, and tenofovir in treatment of DNA virus and retrovirus infections. Clin Microbiol Rev. 2003 Oct; 16(4):569-596.

33. Safrin S, Cherrington J, Jaffe HS. Clinical uses of cidofovir. Rev Med Virol. 1997 Sep; 7(3):145-156.

34. Lalezari J, Schacker T, Feinberg J, Gathe J, Lee S, Cheung T, et al. A randomized, double-blind, placebo-controlled trial of cidofovir gel for the treatment of acyclovir-unresponsive mucocutaneous herpes simplex virus infection in patients with AIDS. J Infect Dis. 1997 Oct; 176(4):892-898.

35. Akhter K. Cytomegalovirus (CMV) Treatment \& Management. Available from: https://emedicine.medscape.com/article/215702-treatment [Accessed: Accessed 5th October 2019].

36. Chou S, Waldemer RH, Senters AE, Michels KS, Kemble GW, Miner RC, et al. Cytomegalovirus UL97 phosphotransferase mutations that affect susceptibility to ganciclovir. J Infect Dis. 2002 Jan; 185(2):162-169.

37. Chou S, Lurain NS, Thompson KD, Miner RC, Drew WL. Viral DNA polymerase mutations associated with drug resistance in human cytomegalovirus. J Infect Dis. 2003 Jul; 188(1):32-39.

38. Chou S, Marousek G, Parenti DM, Gordon SM, LaVoy AG, Ross JG, et al. Mutation in region III of the DNA polymerase gene conferring foscarnet resistance in cytomegalovirus isolates from 3 subjects receiving prolonged antiviral therapy. J Infect Dis. 1998 Aug; 178(2):526-530.

39. Scott GM, Weinberg A, Rawlinson WD, Chou S. Multidrug resistance conferred by novel DNA polymerase mutations in human cytomegalovirus isolates. Antimicrob Agents Chemother. 2007 Jan; 51(1):89-94.

40. Chou S, Miner RC, Drew WL. A deletion mutation in region $\mathrm{V}$ of the cytomegalovirus DNA polymerase sequence confers multidrug resistance. J Infect Dis. 2000 Dec; 182(6):1765-1768.

41. Chou S, Marousek G, Guentzel S, Follansbee SE, Poscher ME, Lalezari JP, et al. Evolution of mutations conferring multidrug resistance during prophylaxis and therapy for cytomegalovirus disease. J Infect Dis. 1997 Sep; 176(3):786-9. 